\title{
Seleksi Pohon Induk Kakao Berdaya Hasil Tinggi Menggunakan Analisis Komponen Utama
}

\section{Selection of High Yielding Cacao Tree Using Principal Component Analysis}

\author{
Imam Hidayat, Taryono*) \\ Departemen Budidaya Pertanian, Fakultas Pertanian, Universitas Gadjah Mada \\ *) Penulis untuk koresponden Email: tariono60@gmail.com
}

\begin{abstract}
Increasing cocoa productivity needs support by the availability of superior planting materials, that have high yield and yield quality, and also resistant to major diseases. This can be realized by germplasm utilization up to testing cross-outs between clones in a population. PT Pagilaran Unit Segayung Utara totally has 280,35 acres of cocoa plantation area originated from sexual propagation. Exploration and selection can be done in these populations to find individual trees that have high yield and good seed quality. The research was observing fruit characteristic of 185 seed originated cocoa trees and comparing to RCC 70, RCC 71 and KKM 4 clones as control. The observed fruit characteristics are fruit length, fruit diameter, fresh fruit weight, number of seeds per fruit, fresh weight of seed per fruit, dry weight of seed per fruit, fruit skin thickness, fresh fruit skin weight, hardness of fruit skin and dry weight per seed. The selection results through the principal components analysis, using the number of seeds, fresh weight of seed, and dry weight per seeds as selection criteria indicated that trees 149, 182 and 233 were potential to be developed as parent trees.
\end{abstract}

Keywords: selection, parent tree, cocoa

\section{INTISARI}

Peningkatan produktivitas kakao perlu didukung oleh ketersedian bahan tanam unggul, yakni bahan tanam yang memiliki daya hasil dan mutu hasil tinggi, serta memiliki ketahanan terhadap penyakit utama. Hal ini dapat diwujudkan melalui berbagai kegiatan mulai dari pemanfaatan plasma nutfah hingga pengujian hasil silangan antar klon dalam suatu populasi. PT Pagilaran Unit Segayung Utara memiliki total luas areal pertanaman kakao asal biji sebesar 280,35 hektar. Dari populasi tersebut dapat dilakukan kegiatan eksplorasi dan seleksi untuk mendapatkan individu pohon yang memiliki daya hasil tinggi serta mutu biji baik. Penelitian di lapangan dilakukan dengan mengamati karakter buah 185 pohon kakao asal biji dengan membandingkan terhadap klon RCC 70, RCC 71 dan KKM 4 sebagai pembanding. Karakter buah yang diamati adalah panjang buah, diameter buah, berat segar buah, jumlah biji per buah, berat segar biji per buah, berat kering biji per buah, tebal kulit buah, berat segar kulit buah, kekerasan kulit buah dan berat kering per biji. Hasil seleksi melalui analisis komponen utama, dengan menggunakan karakter jumlah biji per buah, berat segar biji per buah dan berat kering perbiji sebagai kriteria seleksi menunjukkan bahwa pohon 149, 182 dan 233 berpotensi untuk dikembangkan sebagai pohon induk.

Kata kunci : seleksi, pohon induk, kakao 
Imam Hidayat et al., / Vegetalika. 2018. 7(3): 41-48

\section{PENDAHULUAN}

Kakao (Theobroma cacao L.) merupakan salah satu komoditas perkebunan penting di Indonesia karena termasuk lima besar komoditas perkebunan dengan volume produksi tertinggi setelah kelapa sawit, karet, kelapa, dan tebu. Dari segi jumlah, produktivitas kakao Indonesia cukup rendah yaitu baru mencapai 900 kg biji kering per hektar per tahun dari potensi daya hasil sebanyak $2.000 \mathrm{~kg}$, sedangkan, produktivitas kakao Pantai Gading dapat mencapai 1,5 ton per hektar. Selain itu, mutu biji kakao Indonesia dikatakan kurang baik.

Peningkatan jumlah dan mutu hasil kakao dapat dilakukan melalui program intensifikasi dan ekstensifikasi, yang keduanya memerlukan ketersediaan benih dan bibit kakao unggul berupa bibit hasil perbanyakan secara vegetatif untuk kakao mulia (edel cocoa) atau benih hibrida untuk kakao lindak (bulk cocoa) (Suhendi dkk, 2005). Usaha-usaha yang harus dilakukan untuk memperoleh bahan tanam unggul adalah melakukan kegiatan pemuliaan kakao yang meliputi rangkaian kegiatan seperti koleksi plasma nutfah, pengujian klon, hibridisasi, serta pengujian hasil silangan antar klon.

Seleksi individu pohon merupakan salah satu metode seleksi yang dapat digunakan untuk memperoleh pohon induk berdaya hasil tinggi. Beberapa blok di kebun produksi kakao unit Segayung Utara milik PT Pagilaran masih merupakan kebun asal biji F1 yang tidak diketahui asal tetuanya. Dari populasi tersebut dapat dilakukan kegiatan pengamatan untuk mendapatkan individu pohon yang memiliki daya hasil tinggi serta mutu biji baik. Penelitian ini bertujuan untuk memperoleh individu-individu berdaya hasil tinggi melalui seleksi menggunakan analisis komponen utama.

\section{BAHAN DAN METODE PENELITIAN}

Penelitian dilakukan di kebun produksi kakao PT Pagilaran Unit Segayung Utara blok I. Populasi merupakan tanaman F1 asal biji yang tidak diketahui tetuanya. Dalam populasi tersebut dilakukan pemilihan terhadap 185 tanaman asal biji yang memiliki fenotipe baik. Pohon-pohon terpilih ditandai menggunakan plastik mika serta dilakukan penomoran untuk kemudian dipanen dan diamati karakter buahnya. Buah dari 185 tanaman terpilih selanjutnya dibandingkan dengan karakter buah tiga klon pembanding yaitu KKM04, RCC70 dan RCC71. Pohon pembanding yang digunakan sebanyak 5 pohon untuk masing-masing klon dan diambil masing-masing 5 buah per pohon. Pengamatan dilakukan terhadap sepuluh karakter buah yaitu panjang buah, 
Imam Hidayat et al., / Vegetalika. 2018. 7(3): 41-48

diameter buah, berat segar buah, jumlah biji per buah, berat segar biji per buah, berat kering biji per buah, tebal kulit buah, berat segar kulit buah, kekerasan kulit buah dan berat kering per biji.

Data yang terkumpul kemudian dianalisis menggunakan analisis varians untuk melihat adanya beda nyata antar individu dalam populasi berdasarkan sepuluh karakter buah yang diamati. Koefisien keragaman genetik (KKG) dihitung berdasarkan rumus Singh dan Chaudhary (1979), yaitu:

$$
\mathrm{KKG}=\frac{\sqrt{\sigma_{G}^{2}}}{\bar{x}} \times 100 \%
$$

Koefisien keragaman genotipe dikategorikan menurut Knight (1979) sebagai berikut: Besar (KKG >14,5\%) Sedang ( $5 \%<$ KKG $\leq 14,5 \%$ ) Kecil (KKG $\leq 5 \%)$

Heritabilitas dihitung menggunakan rumus:

$$
H=\frac{\sigma_{G}^{2}}{\sigma^{2} \mathrm{P}}=\frac{\sigma^{2} \mathrm{G}}{\sigma_{\mathrm{G}+}^{2} \sigma^{2} \mathrm{P}}
$$

Kriteria nilai duga heritabilitas menurut Anonim (1981) cit. Manggoendijojo (2003) ialah sebagai berikut: tinggi bila nilai $\mathrm{H}>50 \%$, sedang bila nilai $20 \%<\mathrm{H} \leq 50 \%$, dan rendah bila nilai $\mathrm{H} \leq 20 \%$.

Seleksi pohon induk berdasarkan karakter buah dilakukan melalui penerapan analisis komponen utama atau Principal Component Analysis (PCA). Analisis komponen utama dilakukan dengan menggunakan perangkat lunak STAR (Statistic Tool for Agriculture Research).

\section{HASIL DAN PEMBAHASAN}

Analisis varian terhadap panjang buah, diameter, berat segar buah, jumlah biji perbuah, berat segar biji perbuah, berat kering biji perbuah, tebal kulit, berat segar kulit buah, kekerasan buah dan berat kering perbiji pada populasi kakao asal biji menunjukkan adanya beda nyata dengan tingkat kepercayaan 95\% (Tabel 1). Jumlah biji per buah, tebal kulit, berat segar kulit, dan kekerasan kulit buah menunjukan tidak adanya beda nyata antar tiga klon pembanding (Tabel 2.). 
Imam Hidayat et al., / Vegetalika. 2018. 7(3): 41-48

Tabel 1. Jumlah kuadrat populasi kakao asal biji

\begin{tabular}{lrrl}
\hline \multirow{2}{*}{ Sumber ragam } & \multicolumn{2}{c}{ Jumlah Kuadrat } & \multirow{2}{*}{ Pr $>$ F } \\
\cline { 2 - 3 } & \multicolumn{1}{c}{ Aksesi } & \multicolumn{1}{c}{ Sesatan } & \\
\hline Panjang Buah & 8913,722 & 15624,227 & $<, 0001^{*}$ \\
Diameter & 296,753 & 135,824 & $<, 0001^{*}$ \\
Berat Segar Buah & 5200802,339 & 2592370,103 & $<, 0001^{*}$ \\
Jumlah Biji Perbuah & 21133,904 & 18112,400 & $<, 0001^{*}$ \\
Berat Segar Biji Perbuah & 315324,030 & 186113,777 & $<, 0001^{*}$ \\
Berat Kering Biji Perbuah & 62071,572 & 32319,979 & $<, 0001^{*}$ \\
Tebal Kulit & 49,934 & 23,223 & $<, 0001^{*}$ \\
Berat Segar Kulit & 4178819,778 & 1920020,523 & $<, 0001^{*}$ \\
Kekerasan Buah & 66,145 & 27,494 & $<, 0001^{*}$ \\
Berat Kering Perbiji & 36,936 & 17,570 & $<, 0001^{*}$ \\
\hline db =187, db galat=618 & & &
\end{tabular}

Tabel 2. Jumlah kuadrat populasi kakao asal klon

\begin{tabular}{|c|c|c|c|c|}
\hline \multirow[b]{2}{*}{ Sumber Ragam } & \multicolumn{3}{|c|}{ Jumlah Kuadrat } & \multirow[b]{2}{*}{$\operatorname{Pr}>\mathrm{F}$} \\
\hline & Pembanding & $\begin{array}{l}\text { Pohon dalam } \\
\text { pembanding }\end{array}$ & $\begin{array}{l}\text { Buah dalam } \\
\text { pohon dalam } \\
\text { pembanding }\end{array}$ & \\
\hline Panjang Buah & 118,222 & 50,270 & 80,296 & $0,001^{*}$ \\
\hline Diameter Buah & 17,706 & 7,793 & 16,095 & $0,001^{*}$ \\
\hline Berat Segar Buah & 168970,797 & 197794,949 & 401801,281 & $0,025^{\star}$ \\
\hline Jumlah Biji Perbuah & 227,110 & 987,574 & 1103,283 & $0,289^{\text {ns }}$ \\
\hline Berat Segar Biji Perbuah & 7969,778 & 5360,707 & 14832,209 & $0,004^{*}$ \\
\hline Berat Kering Biji Perbuah & 2700,686 & 1338,436 & 1879,554 & $0,001^{*}$ \\
\hline Tebal Kulit & 0,371 & 1,367 & 2,204 & $0,237^{\mathrm{ns}}$ \\
\hline Berat Segar Kulit & 108648,076 & 178148,441 & 302852,623 & $0,057^{\mathrm{ns}}$ \\
\hline Kekerasan & 0,196 & 2,905 & 3,153 & $0,675^{\mathrm{ns}}$ \\
\hline Berat Kering Perbiji & 1,077 & 1,180 & 0,847 & $0,020^{*}$ \\
\hline \multicolumn{5}{|c|}{$\begin{array}{l}\text { db pembanding }=2 \text { db pohon dalam pembandin } \\
\text { pembanding } 60 \\
\left({ }^{*}\right) \text { beda nyata dengan tingkat kepercayaan } 95 \% \\
(n s) \text { tidak berbeda nyata }\end{array}$} \\
\hline \multicolumn{5}{|c|}{$\begin{array}{l}\text { Luasnya keragaman genetik dapat dilihat dengan menghitung nilai koefisien } \\
\text { gaman genetik (KKG) (Pinaria dkk, 1995). Tingkat keragaman genetik pada } \\
\text { litian ini dapat terlihat dari hasil tiap individu dalam populasi yang beragam. Hal in } \\
\text { t terjadi karena populasi kakao di blok I yang diamati berasal dari hasi } \\
\text { langan bebas tetua klonal dan diperbanyak menggunakan biji. Perbanyakar }\end{array}$} \\
\hline
\end{tabular}


Imam Hidayat et al., / Vegetalika. 2018. 7(3): 41-48

tetua klonal yang digunakan juga bukan merupakan galur murni atau bersifat heterozigot sehingga secara genetik tanamannya beragam.

Tabel 3. Nilai duga heritabilitas arti luas komponen hasil.

\begin{tabular}{lrr}
\hline Karakter & KKG $(\%)$ & $\mathrm{H}^{2}(\%)$ \\
\hline Panjang Buah & 13.29 & 53,42 \\
Diameter & 57.97 & 88,20 \\
Berat Segar Buah & 22.44 & 86,79 \\
Jumlah Biji Perbuah & 15.98 & 77,41 \\
Berat Segar Biji Perbuah & 25.31 & 85,57 \\
Berat Kering Biji Perbuah & 27.23 & 87,44 \\
Tebal Kulit & 23.70 & 87,32 \\
Berat Segar Kulit & 25.65 & 87,63 \\
Kekerasan Buah & 7.23 & 88,20 \\
Berat Kering Perbiji & 32.17 & 88,34 \\
\hline
\end{tabular}

Dari karakter-karakter yang memiliki koefisien keragaman genetik tinggi berpeluang mendapatkan genotipe yang memiliki potensi hasil yang lebih baik dibandingkan potensi hasil yang dimiliki klon-klon pembanding. Keragaman genetik yang luas merupakan salah satu syarat efektifnya program seleksi, dan seleksi untuk suatu karakter yang diinginkan akan lebih berarti jika karakter tersebut mudah diwariskan. Nilai heritabilitas yang tinggi menggambarkan pengaruh keragaman genetik lebih besar terhadap fenotipik sehingga suatu karakter dapat lebih mudah diturunkan ke generasi selanjutnya (Borojevic, 1990).

Tabel 3 menjelaskan bahwa dari sepuluh karakter buah yang diamati, hampir semuanya memiliki nilai koefisien keragaman genetik yang tinggi. Koefisien keragaman tertinggi dalam populasi kakao asal biji di blok I teramati pada diameter buah yakni sebesar 57,9\% (cukup tinggi) dan terendah untuk kekerasan buah sebesar 7,22\% (rendah). Tabel 3 menjelaskan bahwa karakter berat kering per biji merupakan karakter yang memiliki daya waris tertinggi karena memiliki nilai heritabilitas sebesar $88,34 \%$. Sedangkan, karakter lain seperti panjang buah, berat segar buah, jumlah biji per buah, berat segar biji per buah, berat kering biji per buah, berat segar kulit dan berat kering perbiji juga masuk ke dalam kriteria karakter yang memiliki heritabilitas tinggi namun nilainya masih lebih rendah.

\subsection{Analisis Komponen Utama (Principal Component Analysis)}

Kriteria bahan tanam unggul kakao berdasarkan beberapa kriteria diantaranya memliki jumlah biji per buah $>40$ biji serta berat kering per biji $>1$ gram. Hasil 
Imam Hidayat et al., / Vegetalika. 2018. 7(3): 41-48

penelitian Sari dan Susilo (2013) menjelaskan bahwa ada hubungan positif antara karakter berat segar buah, berat segar biji, dan berat kering biji sehingga karakterkarakter tersebut dapat digunakan sebagai kriteria seleksi kakao.

Karakter buah yang dihitung dalam analisis ini merupakan karakter yang berpotensi digunakan sebagai kriteria seleksi. Karakter tersebut masing-masing adalah jumlah biji per buah, berat segar biji per buah dan berat kering perbiji. Karakterkarakter tersebut memiliki nilai korelasi genetik dan fenotipik terhadap berat kering biji per buah dan memiliki nilai heritabilitas yang tinggi.

Tabel 4. Besaran koefisien 10 komponen utama populasi kakao asal biji.

\begin{tabular}{lrrrr}
\hline Peubah & Komponen & Komponen & Komponen & Komponen \\
Utama 1 & Utama 2 & Utama 3 & Utama 4 \\
\hline Jumlah biji per buah & 0.3373 & $\mathbf{0 . 8 0 5 7}$ & -0.3234 & -0.3639 \\
Berat segar biji per buah & $\mathbf{0 . 5 5 3 9}$ & 0.093 & 0.8272 & -0.0158 \\
Berat kering biji per buah & $\mathbf{0 . 5 9}$ & -0.0751 & -0.373 & 0.7121 \\
Berat kering per biji & 0.4809 & $-\mathbf{0 . 5 8 0 1}$ & -0.2683 & -0.6002 \\
\hline Proporsi Keragaman & $\mathbf{0 . 6 8 8 4}$ & $\mathbf{0 . 2 5 5 2}$ & $\mathbf{0 . 0 5 3 4}$ & $\mathbf{0 . 0 0 2 9}$ \\
\hline Proporsi Kumulatif & $\mathbf{0 . 6 8 8 4}$ & $\mathbf{0 . 9 4 3 7}$ & $\mathbf{0 . 9 9 7 1}$ & $\mathbf{1}$ \\
\hline EigenValues & $\mathbf{2 . 7 5 3 7}$ & $\mathbf{1 . 0 2 1}$ & $\mathbf{0 . 2 1 3 7}$ & $\mathbf{0 . 0 1 1 7}$ \\
\hline
\end{tabular}

Berdasarkan hasil analisis komponen utama data seluruh populasi menunjukkan bahwa dua komponen utama pertama telah dapat menerangkan total keragaman sebesar 94,3\% (Tabel 4.). Proporsi varian dua komponen utama pertama (PCA 1) 68,84 dan kedua (PCA 2) 25,52\%, (Tabel 4). Besaran koefisien komponen utama pertama dan kedua (Tabel 4.) menjelaskan bahwa pada komponen utama pertama, koefisien karakter jumlah berat segar biji per buah $(0,554)$ dan berat kering biji per buah $(0,59)$ memiliki nilai yang lebih tinggi pada principle component 1 . Pada komponen kedua, karakter jumlah biji per buah $(0,806)$ dan berat kering per biji $(-5,88)$ memiliki nilai yang lebih tinggi pada principle component 2. 


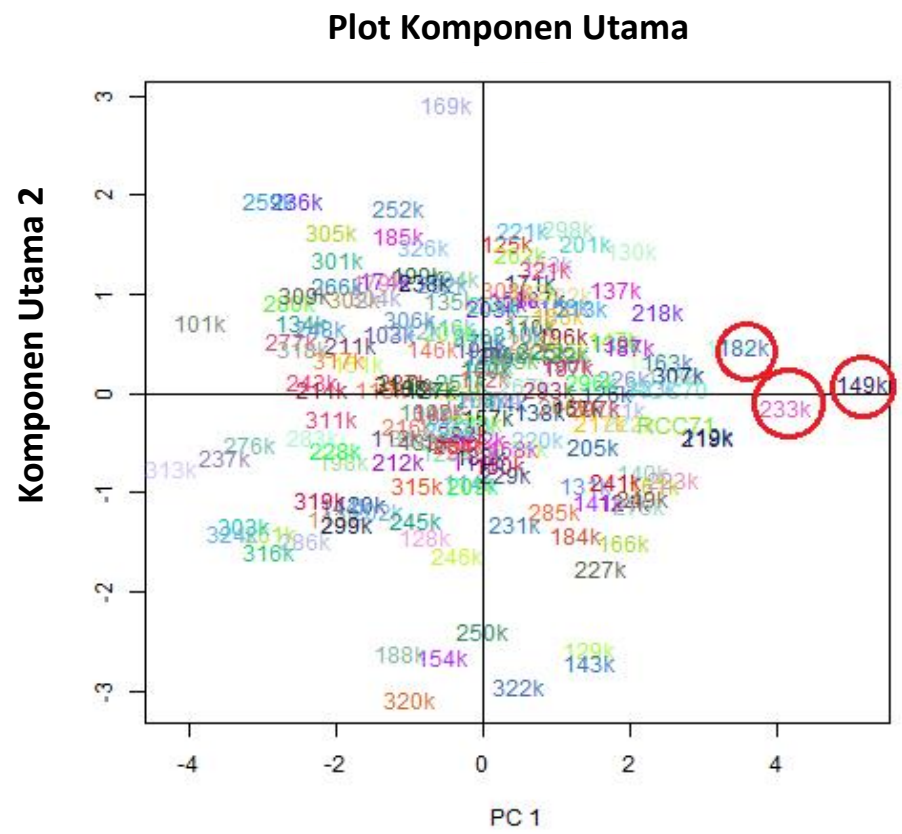

Gambar 1. Diagram titik sebaran seluruh populasi kakao asal biji dalam sistem koordinat komponen utama 1 dan komponen utama 2

Pada Gambar 1, sumbu x menjelaskan PC1 dan sumbu y menjelaskan PC2. PC1 menjelaskan karakter berat segar biji per buah dan berat kering biji per buah. PC2 menjelaskan karakter jumlah biji per buah dan berat kering per biji. Pemilihan pohon menggunakan karakter-karakter pada di PC1 dan PC2 dilakukan pada kuadran I karena akan menghasilkan individu-individu yang secara umum memiliki nilai karakter berat segar biji per buah, berat kering biji per buah, jumlah biji per buah dan berat kering per biji yang tinggi.

Pohon-pohon terpilih selanjutnya akan dijadikan sebagai pohon induk yang kemudian dikembangkan melalui perbanyakan vegetatif. Perbanyakan tanaman melalui teknik perbanyakan vegetatif akan meghasilkan individu-individu yang lebih homogen. Namun sebelum upaya perbanyakan tanaman dilakukan perlu adanya kegiatan pemeliharaan tanaman yang intensif, terutama dari segi pemangkasan. Menurut Siregar dkk (2007) melalui kegiatan pengelolaan tajuk yang baik nantinya akan mempermudah kegiatan pemangkasan, baik pemangkasan bentuk maupun pemangkasan pemeliharaan pada tanaman hasil perbanyakan vegetatif. Pemeliharaan tunas air dan cabang plagiotrop dilakukan sebagai sumber mata tunas dan stek. 
Imam Hidayat et al., / Vegetalika. 2018. 7(3): 41-48

\section{KESIMPULAN}

1. Pohon yang berpotensi untuk dikembangkan sebagai pohon induk berdasarkan karakter buah yang dimiliki adalah pohon nomor 149, 182 dan 233.

2. Karakter jumlah biji berat segar biji per buah dan berat kering per biji berkorelasi nyata positif terhadap karakter berat kering biji per buah.

3. Karakter jumlah biji, berat segar biji per buah, berat kering per biji dan berat kering biji per buah memiliki nilai heritabilitas tinggi sehingga dapat digunakan sebagai kriteria seleksi.

\section{DAFTAR PUSTAKA}

Borojevic, S. 1990. Principles and Methods of Plant Breeding. Elsevier Sd. Pub. Co. Inc. New York.

Knight, R. 1979. Quantitative genetics statistics and plant Breeding. Brisbane, Australia.

Laode, A. 2004. Seleksi dan karakterisasi morfologi tanaman kakao harapan tahan penggerek buah kakao (conompomorpha cramerella Snell.). Jurnal Sains dan Teknologi : 109-122.

Mangoendijojo, W. 2003. Dasar-Dasar Pemuliaan Tanaman. Kanisius. Yogyakarta.

Pinaria A, Baihaki A, Setiamiharja R, Daradjat AA. 1995. Variabilitas genetik dan heritabilitas karakter-karakter biomassa 53 genotipe kedelai. Zuriat 6(2):8892.

Sari, A.I dan Susilo, A.W. 2013. Pengembangan Kriteria Seleksi Karakter Berat Biji pada Tanaman Kakao (Theobroma cacao L.) melalui Pendekatan Analisis Sidik Lintas. Pelita Perkebunan 29(3): 174-181

Singh, R.K, dan Chaudhary, B.D., 1979, Biometrical methods in quantitative genetic analysis, Kalyani Publisher, Ludhiana, New Delhi.

Siregar T.H.S., S. Riyadi, dan L. Nuraeni. 2007. Budidaya, Pengolahan dan Pemasaran Coklat. Penebar Swadaya. Jakarta.

Suhendi, D., W.S. Agung, dan S. Mawardi. 2004. Analisis daya gabung karakter pertumbuhan vegetative beberapa klon kakao (Theobroma cacao L). Jurnal Pelita Perkebunan 15: 64-72. 